\title{
Analysis of the Causal Relationship between Precious Metal Prices and Inflation: Evidence from Ethiopia
}

\author{
Submitted 04/11/21, 1st revision 07/12/21, 2nd revision 09/01/22, accepted 05/02/22
}

\section{Desta Bati Nuno ${ }^{1}$}

\begin{abstract}
:
Purpose: Keeping inflation stability is the main challenge in Ethiopia. One of the reasons for this could be fluctuation in commodity price specifically, precious metal price. Therefore, this study aims to analyze the causal relationship between precious metal prices and inflation in Ethiopia.

Design/Methodology/Approach: The monthly time series data from January 2000 up to April 2021 was used. The Augmented Dickey-Fuller (ADF) and Phillips-Perron (PP) tests of unit root were employed to examine whether the series became stationary or not at level. The Johanson co-integration test was implemented to determine the co-integration of the variables. After stationarity and integration tests were performed, the Vector Autoregressive model (VAR) was employed to estimate the model. After model estimation, VAR Granger causality was tested to check the causal relationship between the variables.

Findings: $A D F$ and PP test indicate that variables under study are stationary after the first difference. The trace statistic and the maximum eigen-value test of co-integration showed that there is no co-integrating vector at 0.05 level of significance. VAR estimation result shows that one and two-period lag of gold price, one and two-period lag of silver price, one and two-period lag of platinum price, and one-period and two-period lag of CPI had a statistically significant effect on inflation (CPI) in the short-run. The granger causality analysis results indicated that there was a statistically significant causality between CPI and platinum prices.

Practical Implications: These results may be used to guide policymakers in terms of where emphasis should be given regarding inflation instability in Ethiopia.

Originality/Value: The results of this study revealed that inflation and precious metal price have short-run causal relationship and no prior result that could be aligned or contrary to this result in Ethiopia.
\end{abstract}

Keywords: Causality, Co-integration, Inflation, Precious metal price, Short-run, VAR.

JEL Classification: C49, C58, E31.

Research Type: Research Article.

\footnotetext{
${ }^{1}$ Haramaya University, College of Computing and Informatics, Department of Statistics, destabati8@gmail.com;
} 


\section{Introduction}

Throughout history, investors have endeavored to determine the future states and prices of instruments that they consider investing in. Thus, various econometric models have been developed to determine the variables influencing the prices of investment instruments, as well as the relationships between such variables (Mehmet, 2017). Precious metals such as gold, silver, and platinum which have high economic value and are as important as money throughout history but are mostly used for industrial or investment purposes nowadays, have recently attracted many decision-makers attention. In most parts of the world, precious metals, especially gold, are a reserve instrument for central banks, an internationally recognized and strategic instrument for speculators and hedge funds, an input for industrial users, and an important investment and wealth storage tool for savings holders. For this reason, these instruments which have high transaction volume in the markets have high cash flow in the world (Durmuş et al., 2020). Precious metal prices are vital variables in financial models for revenue evaluation, which forms the basis of an effective payment regime used by resource policymakers (Chang et al., 2017).

In today's Ethiopian economy determining precious metal prices concerning inflation is very important because precious metal prices like gold, silver, and platinum gained considerable attention for their potential effect on inflation even taken as a leading indicator of inflation. Gold and silver prices are factors evidenced as causing inflation at a high level (Abdur Rahman et al., 2016). According to Kearney and Lombra (2009), precious metals such as gold and platinum are considered to be attractive assets in periods of high inflation and economic and political instability.

Since Inflation is a worldwide macroeconomic problem and the inter-relationship between inflation and commodity markets is one of the most challenging issues for investors (Korhan and Negar, 2015), particularly determining inflation in Ethiopia have multidimensional implications. Even though some literature was developed on the determinant and causality of inflation with other macroeconomic variables in Ethiopia (Mebratu, 2020; Teamrat, 2017) literature is scarce on the causal relationship between precious metal price and inflation in Ethiopia. At this time when inflation is highly influencing the economy and life of the people in the country studying its relationship with the international price of precious metals is crucial for investors, traders, government, non-government, and all concerning bodies.

Therefore, this study aims to investigate causality and co-integration between precious metal (gold, silver, and platinum) price and inflation in Ethiopia.

\section{Literature Review}

There are many studies devoted to the relationship between inflation and other macroeconomic variables (Christopher and Johannes, 2011; Eftekhari and Kiaee, 
2015; Osborn et al., 2016; Wondimu, 2020; Yen Chee and Sek, 2015). In contrast, only a few studies have been devoted to examining the relationship between precious metal (gold, silver, and platinum) prices and inflation. Lucey et al. (2016) studied gold and inflation time-varying relationship for the time between 1974 and 2014 in the united states and conclude that gold is co-integrated with inflation.

Bampinas and Panagiotidis (2015), examined gold and silver hedge against inflation with a dataset from 1791 to 2010 for the US and the UK and finally conclude that there is stronger evidence in favor of time-varying long-run relationship between gold and silver prices and the alternative price level measures, relative to the timeinvariant approach for both countries.

Abdur Rahman et al. (2016), studied the role of gold price, interest rate, and exchange rate against inflation utilizing data throughout 1975-2013 under the Johansen co-integration and vector error correction model. The results of their study revealed that gold prices and interest rates are related to inflation in the long run. The study conducted by Joseph (1998), and Mahdavi and Zhou (1997), has shown that gold price is a leading indicator of inflation. Statistically, when the gold price is collated with other variables like oil price, there is a very strong relationship between the gold price and inflation (Raphael, 2012).

Saira and Sadia (2013), made use of time series econometric technique (cointegration and vector error correction models) to analyze the relationship between inflation and gold price in Pakistan for the period of 1960-2010, their results demonstrated that gold price is a potential determinant of inflation in Pakistan.

Anandasayanan et al. (2019), examined the relationship between inflation and gold price by using monthly data from January 1999 to December 2018 and the research findings indicate that there is a strong and positive association between inflation and gold price. In addition to this, the study showed that significant impacts of inflation on the gold price, and granger causality found that there is a unidirectional relationship between gold price and inflation.

\section{Research Methodology}

\subsection{Data Source}

This study examined the causal relationship of precious metal prices namely gold, platinum, and silver prices with Ethiopian inflation from January 2000 to April 2021. The data of precious metal price measured in US dollar per troy oz was obtained from the world bank commodity price database (the pink sheet). We use the consumer price index (CPI) as a proxy for inflation because CPI is the most commonly used index for measuring inflation (Osborn et al., 2016; Pradhan and Bagchi, 2013), and data were obtained from the national bank of Ethiopia and 2010 was a base year. 


\subsection{Model Specification}

Since the data used for this study were time-series data, such data were subjected to stationarity analysis and causality analysis initially. Augmented Dickey-Fuller (ADF) test, Philips Peron (PP) test, Kwiatkowski-Phillips-Schmidt-Shin (KPSS) tests and ADF-GLS test are among of unit root tests used for stationarity analysis. Among these unit root tests, Augmented Dickey-Fuller (ADF) test and Philips Peron (PP) test were applied for this study. Time-series data is said to be stationary when its mean and variance are similar over the given time and the covariance that exists between the two variables was invariant in the observed time.

\subsubsection{The Augmented Dickey-Fuller (ADF) Test}

The ADF test builds a parametric adjustment for higher-order correction by assuming that the series $\mathrm{Y} t$ follows autoregressive, $\mathrm{AR}(\mathrm{p})$ process with the order of lag $\mathrm{p}$ (Dickey and Fuller, 1979). Thus, the test has been done adding $\mathrm{p}$ lagged difference terms of the dependent variable as an independent variable on the righthand side of the test regression. The ADF test includes extra lagged in terms of the dependent variables to distribute with autocorrelation (Afriyie et al., 2020). The null hypothesis of the ADF test is $H_{0}$ : The time series is not stationary versus the alternative hypothesis $H_{1}$ : The time series is stationary. The ADF test employs the following regression model:

$$
\Delta Y_{t}=\beta_{1}+\beta 2 t+\delta Y_{t-1}+\sum_{i=1}^{p} \alpha_{i} \Delta Y_{t-i}+\varepsilon t
$$

Where, $\Delta=$ is the first difference operator, $\beta 1, \beta_{2}, \delta$, and $\alpha$ are coefficients, $\mathrm{t}$ is the stochastic time-trend, $\Delta Y_{t-i}=$ is the lagged values of the dependent variable, for example, $\quad \Delta Y_{t-1}=\left(Y_{t-1}-Y_{t}-2\right), \Delta \mathrm{Y}_{\mathrm{t}-2}=\left(\mathrm{Y}_{\mathrm{t}-2}-\mathrm{Y}_{\mathrm{t}-3}\right)$, and so forth; $E_{t}$ is $\quad$ a white noise error term.

\subsubsection{The Phillips Perron (PP) Test}

The PP test builds on the DF test and makes a non-parametric correction to the t-test statistic. It is an alternative technique for unit root tests that discounts any serial correlation in the error term without adding lagged difference terms. One advantage of the PP test over the ADF test is that the PP test is robust to general forms of heteroscedasticity in the error term $\varepsilon_{t}$ (Afriyie et al., 2020).

\subsubsection{Co-integration Test}

After the stationarity test, the next step was to perform a test for co-integration between inflation, gold price, platinum price, and silver price. This kind of test is carried out if endogenous variables under study are not stationary at the level but stationary at the first difference (Rahim et al., 2021). The co-integration test used was the Johansen co-integration test developed by (Johansen, 1988). This co- 
integration test can be used if all endogenous variables are integrated in the same order. Two types of tests used in the Johansen co-integration test are the trace test and the Max-Eigen test. Both tests are used in this study. Trace test uses the following test statistics.

$\lambda_{\text {trace }}(r)=-T \sum_{i=r+1}^{g} \log (1-\lambda i), r=0,1, \ldots g-1$

Where $\lambda i$ is the largest Eigen value and $\mathrm{T}$ is the number of observations. The formula for the null hypothesis in the trace test is $H_{0}$ : The number of co-integrating vectors is less or equal to $\mathrm{r}$, versus the alternative hypothesis $H_{1}$ : The number of cointegrating vectors is more than $\mathrm{r}$. The max-eigen test statistic can be given as

$$
\lambda \max (r, r+1)=-T \log (1-\lambda r+1), \mathrm{r}=0,1, \ldots, \mathrm{g}-1
$$

The null hypothesis of the max-eigen test is $H_{0}$ : The number of co-integrating vectors is $r$, and the alternative hypothesis is $H_{1}$ : The number of co-integrating vectors is $r+1$.

\subsubsection{Vector Autoregressive Model (VAR)}

The vector autoregressive (VAR) model is a common framework used to express the dynamic interrelationship among stationary variables. So, the first step in time series analysis should be to decide whether the levels of the data are stationary. If not stationary, take the first differences of the series and try again (Murad and Beyan, 2021). The Vector Autoregressive (VAR) model and Granger causality test are used to test the relationships between inflation, gold price, platinum price, and silver price for this study.

The analysis and result of the study are discussed widely under the result and discussion part. Specifically, VAR models used to see the relationship between CPI, gold, silver, and platinum are given as follows:

$$
\begin{aligned}
& C P I t=\alpha 0+\sum_{i=1}^{p=2} \alpha{ }_{1 i} C P I t-i+\sum_{j=1}^{p=2} \alpha 2 j G t-j+\sum_{k=1}^{p=2} \alpha 3 k S t-k+\sum_{l=1}^{p=2} \alpha 4 l P t-l+\varepsilon 1 t \\
& G t=\beta 0+\sum_{i=1}^{p=2} \beta 1 i C P I t-i+\sum_{j=1}^{p=2} \beta 2 j G t-j+\sum_{k=1}^{p=2} \beta 3 k S t-k+\sum_{l=1}^{p=2} \beta 4 l P t-l+\varepsilon 2 t
\end{aligned}
$$




$$
\begin{aligned}
& S t=\gamma 0+\sum_{i=1}^{p=2} \gamma 1 i C P I t-i+\sum_{j=1}^{p=2} \gamma 2 j G t-j+\sum_{k=1}^{p=2} \gamma 3 k S t-k+\sum_{l=1}^{p=2} \gamma 4 l P t-l+\varepsilon 3 t \\
& P_{t}=\delta 0+\sum_{i=1}^{p=2} \delta_{1 i} C P I_{t}-i+\sum_{j=1}^{p=2} \delta_{2 j} G_{t}-j+\sum_{k=1}^{p=2} \delta_{3 k} S_{t}-k+\sum_{l=1}^{p=2} \delta 4 l P t-l+\varepsilon 4 t
\end{aligned}
$$

In the equations given above, $C P I$ refers to the differenced values of the consumer price index (a proxy for inflation); $G$ refers to the differenced values of gold prices; $S$ refers to the differenced values of silver prices, and $P$ refers to the differenced values of platinum prices.

Underestimating the assumption of normal distribution may lead to type 1 and type 2 errors (Mehmet, 2017). To increase the normality of the variables, to change measurement levels, and to stabilize the variance data, transformation should be conducted. Taking this into account first difference of all variables were calculated for data transformation under this study.

\section{Discussion}

\subsection{Unit Root Test}

Any time series data should be checked for stationary before one can attempt to fit an appropriate model. The augmented Dickey-Fuller (ADF) and Phillips and Perron (PP) test were used for the stationary analysis. The ADF unit root test results for both level and first differences are presented in Table 1. According to these results, the variables were not stationary at level, but their first differences were stationary. Thus, the variable is integrated of order one, denoted by I (1). Graphically the overview of the first differenced data are shown by Figure 1. It shows that after the data was differentiated trends are fluctuating around constant mean and this shows stationarity of our data after differencing.

\subsection{Co-integration Analysis}

A co-integration analysis was made to reveal whether or not there is a long-term relationship between the variables. Lack of co-integration means the lack of a longterm relationship between the given variables. It tests the null hypothesis suggesting that there is no co-integration against the existence of co-integration and employs eigenvalue and trace statistic values as test statistics. The co-integration test determines the type of the regression model to be applied VAR or VECM (Pradhan and Bagchi, 2013). The test results about co-integration of inflation (CPI) with gold price, silver price, and platinum price for both trace test and Max-Eigen value test are given in Table 2. 
Figure 1. First differences of the variables used in the analysis
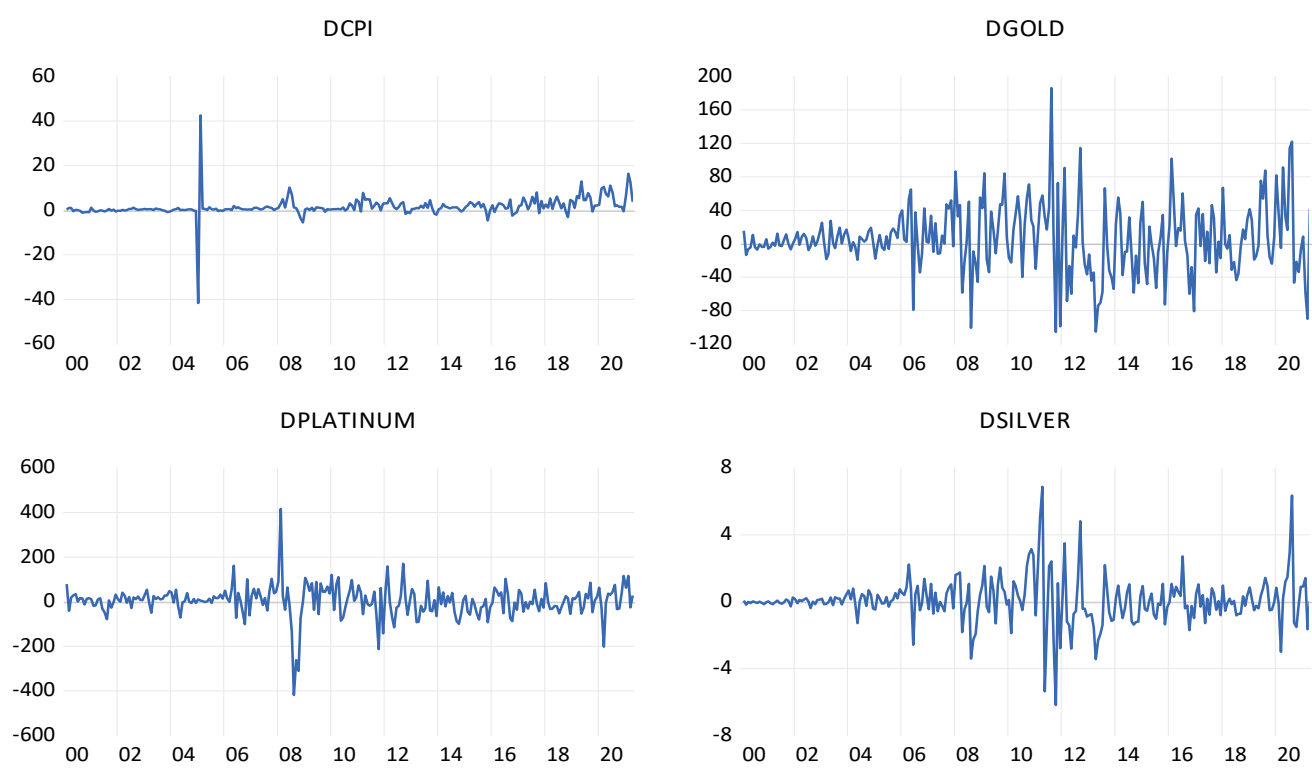

Source: Own calculation.

Table 1. The results of the augmented dickey-fuller stationary analysis

\begin{tabular}{|c|c|c|c|c|c|c|c|c|}
\hline \multirow{3}{*}{ Series } & \multicolumn{4}{|c|}{ Level I(0) } & \multicolumn{4}{|c|}{ First difference I(1) } \\
\hline & \multicolumn{2}{|c|}{ t-statistic } & \multicolumn{2}{|c|}{ Prob* } & \multicolumn{2}{|c|}{ t-statistic } & \multicolumn{2}{|c|}{ Prob* } \\
\hline & $\mathrm{ADF}$ & PP & $\mathrm{ADF}$ & $\mathrm{PP}$ & $\mathrm{ADF}$ & PP & $\mathrm{ADF}$ & $\mathrm{PP}$ \\
\hline CPI & -2.80 & -2.72 & 0.197 & 0.230 & -8.95 & -9.09 & 0.00 & 0.00 \\
\hline Gold & -0.94 & -1.08 & 0.948 & 0.929 & -13.91 & -13.88 & 0.00 & 0.00 \\
\hline Platinum & -1.96 & -2.15 & 0.620 & 0.515 & -12.17 & -12.24 & 0.00 & 0.00 \\
\hline Silver & -1.71 & -1.51 & 0.742 & 0.822 & -12.41 & -12.42 & 0.00 & 0.00 \\
\hline \\
\hline \multirow[t]{3}{*}{ value } & \multicolumn{2}{|c|}{$1 \%$} & \multicolumn{2}{|l|}{-3.9947} & & \multicolumn{3}{|c|}{-3.9945} \\
\hline & \multicolumn{2}{|c|}{$5 \%$} & \multicolumn{2}{|l|}{-3.4276} & & \multicolumn{3}{|c|}{-3.4276} \\
\hline & \multicolumn{2}{|c|}{$10 \%$} & \multicolumn{2}{|l|}{-3.1371} & & \multicolumn{3}{|c|}{-3.1371} \\
\hline
\end{tabular}

Source: Author own estimates *MacKinnon (1996) one-sided p-value.

Table 2. Johansen co-integration test results for CPI with gold, silver, and platinum

\begin{tabular}{llllllll}
\hline $\begin{array}{l}\text { Cointegration } \\
\text { Rank }\end{array}$ & $\begin{array}{l}\text { Eigen } \\
\text { value }\end{array}$ & $\begin{array}{l}\lambda \text { trace }(\text { Trace } \\
\text { Statistic) }\end{array}$ & $\begin{array}{l}5 \% \\
\text { critical } \\
\text { value }\end{array}$ & Prob. & $\begin{array}{l}\lambda \text { max } \\
\text { (Max- } \\
\text { Eigen) }\end{array}$ & $\begin{array}{l}5 \% \\
\text { critical } \\
\text { value }\end{array}$ & Prob. \\
\hline 0 & 0.072 & 46.742 & 47.856 & 0.063 & 18.251 & 27.584 & 0.474 \\
1 & 0.057 & 28.491 & 29.797 & 0.070 & 14.276 & 21.132 & 0.342 \\
2 & 0.052 & 14.215 & 15.494 & 0.077 & 12.963 & 14.265 & 0.079 \\
3 & 0.005 & 1.253 & 3.841 & 0.263 & 1.253 & 3.841 & 0.263 \\
\hline
\end{tabular}

Source: Author own calculation. 
Since the trace statistic value $(r=0 ; \lambda$ trace $=46.742)$ is lower than the $5 \%$ critical value (47.856), and the max statistics value $(r=0, \lambda \max =18.251)$ is lower than the $5 \%$ critical value (27.584), the null hypothesis cannot be rejected. This result shows that there was no co-integration between CPI, gold, silver, and platinum prices. Since no co-integration was detected between the variables, it was necessary to investigate short-term causality, but not long-term causality between the variables.

\subsection{Lag Length Selection}

As inflation, gold price, platinum price, and silver price do not co-integrate, the VAR model to be estimated is that of the first difference. Therefore, the first step in the VAR estimation is to determine the lag length. FPE (Final prediction error), AIC (Akaike information criterion), SC (Schwarz information criterion), and HQ (Hannan-Quinn information criterion) were used to determine the appropriate lag length (Table 3). The appropriate lag length is the one that has the lowest statistical value among the criteria. Based on this lag two was selected by all criteria.

Table 3. Statistical value of information criteria

\begin{tabular}{lllll}
\hline Lag & FPE & AIC & SC & HQ \\
\hline 0 & $1.62 \mathrm{e}_{+} 14$ & 44.0677 & 44.12374 & 44.09026 \\
1 & 99215263 & 29.76429 & 30.04440 & 29.87700 \\
2 & $76925201^{*}$ & $29.50973^{*}$ & $30.01393^{*}$ & $29.71261^{*}$ \\
3 & 78213092 & 29.52609 & 30.25438 & 29.81914 \\
4 & 78437656 & 29.52850 & 30.48089 & 29.91172 \\
\hline
\end{tabular}

Note: $*$ is shows the lowest statistical value of the information criteria: FTE, AIC, SC, HQ.

Source: Author own calculation

\subsection{Vector Autoregressive Model (VAR) Estimation}

Before directly coming to VAR model estimation stationarity and co-integration was the basic requirement to be determined. The result of ADF and PP tests provides sufficient verification of stationarity of the variables (Table 1) at first difference. according to the results of the co-integration test (Table 2), there was no cointegration relationship between the variables. Since the series was not co-integrated and non-spurious, it was appropriate to determine VAR Model.

The results concerning VAR estimation are given in Table 4. The VAR result shows that one and two-period lag of gold price $\left(\alpha_{21}=0.001, \mathrm{t}=0.00\right.$ and $\alpha_{22}=0.004, \mathrm{t}=$ 1.34), one and two-period lag of silver price $\left(\alpha_{31}=-0.003, \mathrm{t}=-0.11\right.$ and $\alpha_{32}=0.007, \mathrm{t}$ $=0.03)$, one and two-period lag of platinum price $\left(\alpha_{41}=0.059, \mathrm{t}=2.78\right.$ and $\alpha_{42}=-$ $0.051, \mathrm{t}=-2.50)$ had statistically significant effect on (CPI) at $5 \%$ level of significance.

One-period and two-period lag of CPI $\left(\alpha_{11}=1.447, \mathrm{t}=25.43\right.$ and $\alpha_{12}=-0.448, \mathrm{t}=$ 7.75 ) had statistically significant effect on consumer price index (CPI) at $10 \%$ level of significance. 
Table 4. Estimated VAR Coefficient

\begin{tabular}{|c|c|c|c|c|}
\hline $\begin{array}{l}\text { Explanatory } \\
\text { variables }\end{array}$ & DCPI & DGold & DSilver & DPlatinum \\
\hline DCPI (-1) & $1.447 *(25.43)$ & $-0.136(-0.96)$ & $-0.186(-0.74)$ & $-0.437(-2.09)$ \\
\hline DCPI (-2) & $-0.448 *(-7.75)$ & $0.105(0.73)$ & $0.083(0.33)$ & $0.338(1.59)$ \\
\hline DGold (-1) & $0.001 *(0.00)$ & $1.083 *(11.44)$ & $-0.108(-0.65)$ & $0.003(0.02)$ \\
\hline DGold (-2) & $0.004 * *(1.34)$ & $-0.001 *(-0.09)$ & $0.393(2.22)$ & $0.198 * *(6.57)$ \\
\hline DSilver $(-1)$ & $-0.003 * *(-0.11)$ & $0.031 *(0.54)$ & $1.146(11.40)$ & $0.055 *(0.65)$ \\
\hline DSilver (-2) & $0.007 *(0.03)$ & $-0.080 *(-1.40)$ & $-0.312(-3.12)$ & $-0.101 *(-1.21)$ \\
\hline DPlatinum(-1) & $0.059 * *(2.78)$ & $-0.032 *(-0.60)$ & $0.077 *(0.82)$ & $1.146 *(14.72)$ \\
\hline DPlatinum(-2) & $-0.051 * *(-2.50)$ & $0.024 * *(0.47)$ & $-0.118 *(-1.32)$ & $-0.250 *(-3.34)$ \\
\hline Constant $(\mathrm{C})$ & $-0.065 *(-1.22)$ & $-0.218(-1.64)$ & $-0.743(-3.17)$ & $-0.044(-0.23)$ \\
\hline
\end{tabular}

Note: **significant at 5\%. *significant at $10 \%$. Values in () are $t$-statistics.

Source: Author own calculation.

The first lag of gold price $\left(\beta_{21}=1.083, \mathrm{t}=11.44\right)$, the first lag and second lag of silver price $\left(\beta_{31}=0.031, \mathrm{t}=0.54\right.$ and $\left.\beta_{32}=-0.080, \mathrm{t}=-1.40\right)$ and the first lag of platinum price $\left(\beta_{41}=-0.032, \mathrm{t}=-0.60\right)$ had statistically significant effect on gold price at $10 \%$ level of significance. The second lag of gold price $\left(\beta_{22}=-0.001, t=-\right.$ $0.09)$ and the second lag of platinum price $\left(\beta_{42}=0.024, \mathrm{t}=0.47\right)$ had statistically significant effect on gold price at $5 \%$ level of significance.

The fist and the second lag of platinum price $\left(\gamma_{41}=0.077, \mathrm{t}=0.82\right.$ and $\gamma_{42}=-0.118$, $\mathrm{t}=-1.32$ ) had statistically significant effect on silver price at $10 \%$ level of significance. The first and the second lag of silver price $\left(\delta_{31}=0.055, \mathrm{t}=0.65\right.$ and $\left.\delta_{32}=-0.101, \mathrm{t}=-1.21\right)$, the first and the second lag of platinum price $\left(\delta_{41}=1.146, \mathrm{t}\right.$ $=14.72$ and $\delta_{42}=-0.250, \mathrm{t}=-3.34$ ) had statistically significant effect on platinum price at $10 \%$ level of significance. The second lag of gold price $\left(\delta_{22}=0.198, \mathrm{t}=\right.$ 6.57 ) had significant effect on platinum price at $5 \%$ level of significance.

\subsection{Causality Analysis}

The VAR Granger Causality/block Exogeneity Wald Tests were also tested to see the direction of the causal relationship between the variables. This causality test uses the Chi-square distribution of wald-statistics. The results of the causal relationship test are shown in (Table 5).

Table 5. VAR Granger Causality/Block Exogeneity Wald Test

\begin{tabular}{llll}
\hline $\begin{array}{l}\text { Dependent } \\
\text { variable }\end{array}$ & $\begin{array}{l}\text { Independent } \\
\text { variable }\end{array}$ & $\begin{array}{l}\text { Chi-square } \\
\text { statistic }\end{array}$ & Prob. \\
\hline DCPI & DGold & 0.090112 & 0.9559 \\
& DPlatinum & 7.763162 & $0.0206 * *$ \\
& DSilver & 0.048570 & 0.9760 \\
& All & 20.44719 & $0.0023 * * *$ \\
DGold & DCPI & 5.294701 & $0.0708 *$ \\
& DPlatinum & 0.429200 & 0.8069 \\
& DSilver & 6.166181 & $0.0458^{* *}$
\end{tabular}




\begin{tabular}{llll}
\multirow{5}{*}{ DPlatinum } & All & 9.340259 & 0.1553 \\
& DCPI & 25.41964 & $0.0000 * * *$ \\
& DGold & 16.01014 & $0.0003 * * *$ \\
& DSilver & 3.091785 & 0.2131 \\
& All & 27.30802 & $0.0001 * * *$ \\
\multirow{5}{*}{ DSilver } & DCPI & 15.41794 & $0.0004 * * *$ \\
& DGold & 28.08499 & $0.0000 * * *$ \\
& DPlatinum & 2.901735 & 0.2344 \\
& All & 26.54707 & $0.0002 * * *$ \\
\hline
\end{tabular}

Note: 'All' means the Granger causality test set for all independent variables. ***significant at $1 \%$. **significant at $5 \%$. *significant at $10 \%$.

Source: Author own calculation.

VAR (2) model and Granger causality test demonstrate that there was a statistically significant causality between CPI and platinum prices $(C P I \leftrightarrow P)$. The causality relationship between CPI and gold price reveals that there is a statistically significant short-term causality of CPI to gold price $(C P I \rightarrow G)$. This result is consistent with Anandasayanan et al. (2019).

Furthermore, the result indicated causality from silver price to gold price $(S \rightarrow \mathrm{G})$, gold price to platinum price $(G \rightarrow \mathrm{P})$, CPI to silver price $(C P I \rightarrow \mathrm{S})$. Moreover, a statistically significant short-term causality was detected from gold prices to silver prices $(G \rightarrow S)$ at a $5 \%$ level of significance and this result is aligned with the result of (Mehmet, 2017).

\section{Conclusions and Recommendations}

In the financial market precious metal price especially gold price and inflation plays a major part. Companies, households, governments, investors, etc. require stable inflation. This study focuses on investigating the causal relationship between the precious metal price (gold, silver, and platinum) and inflation in Ethiopia.

The monthly time series data on CPI as a proxy for inflation, gold price, platinum price, and silver price were analyzed in this study. The stationarity analysis shows that the four-time series: CPI, gold price, platinum price, and silver price are stationary at first deference.

As shown by Johansen's co-integration test, the variables of CPI, gold price, platinum price, and silver price are not co-integrated which implies that there was no long-run relationship between inflation and precious metal prices during the study period. Meanwhile, the estimation results of the VAR (2) model and the granger causality test at first difference indicate that there was a significant short-term relationship between inflation and precious metal price in Ethiopia.

Study recommended policymakers to give emphasis on precious metal price to manage inflation instability in Ethiopia. 


\section{References:}

Abdur Rahman, A., Tariq, M., Ahmed, S. 2016. The Role of Gold Prices, Exchange Rate and Interest Rate on the Continuity of Inflation in Pakistan. Pakistan Business Review, March, 37-54.

Afriyie, J.K., Twumasi-Ankrah, S., Gyamfi, K.B., Arthur, D., Pels, W.A. 2020. Evaluating the performance of unit root tests in single time series processes. Mathematics and Statistics, 8(6), 656-664. https://doi.org/10.13189/ms.2020.080605.

Anandasayanan, S., Thevananth, J., Mathuranthy, A. 2019. The Relationship Between Inflation and Gold Price: Evidence From Sri Lanka. International Journal of Accounting and Financial Reporting, 9(4), 322-333. https://doi.org/10.5296/ijafr.v9i4.15750.

Bampinas, G., Panagiotidis, Th. 2015. Are gold and silver a hedge against inflation? A two century perspective. International Review of Financial Analysis, 41, 267-276. https://doi.org/10.1016/j.irfa.2015.02.007.

Chang, L., Hu, Z., Li, Y., Liu, S. 2017. Forecasting copper prices by decision tree learning. Resources Policy, 52, 427-434. https://doi.org/10.1016/j.resourpol.2017.05.007.

Christopher, P.R., Johannes, F.U. 2011. The effect of inflation on real commodity prices. Kiel Working Paper, No. 1704.

Dickey, D.A., Fuller, W.A. 1979. Distribution of the Estimators for Autoregressive Time Series With a Unit Root. Journal of the American Statistical Association, 74(366), 427431.

Durmuş, Y., Cevik, E.I., Esen, Ö. 2020. Time-varying volatility spillovers between oil prices and precious metal prices. Resources Policy, 68. https://doi.org/10.1016/j.resourpol.2020.101783.

Eftekhari, M.S., Kiaee, H. 2015. Determinants of Inflation in Selected Countries. Journal of Money and Economy, 10(2), 113-143. https://doi.org/10.5089/9781451872293.001.

Johansen, S. 1988. Statistical analysis of cointegration vectors. Journal of Economic Dynamics and Control, 12, 231-254. https://doi.org/10.1016/0165-1889(88)90041-3.

Joseph, G.H. 1998. Gold Prices. In Federal Reserve Bank of Cleveland. http://www.clevelandfed.org/research/commentary/1998/0301.pdf?WT.oss=gold prices\&WT.oss_r $=446$.

Kearney, A.A., Lombra, R.E. 2009. Gold and Platinum: Toward solving the price puzzle. Quarterly Review of Economics and Finance, 49(3), 884-892. https://doi.org/10.1016/j.qref.2008.08.005.

Korhan, K.G., Negar, F. 2015. The Interactions among Gold, Oil, and Stock Market: Evidence from S\&P 500. Procedia Economics and Finance, 25, 478-488. https://doi.org/10.1016/s2212-5671(15)00760-1.

Lucey, B.M., Sharma, S.S., Vigne, S. 2016. Gold and Inflation (s) - A Time-Varying Relationship. Economic Modelling. https://doi.org/https://doi.org/10.1016/j.econmod.2016.10.008.

Mahdavi, S., Zhou, S. 1997. Gold and commodity prices as leading indicators of inflation: Tests of long-run relationship and predictive performance. Journal of Economics and Business, 49(5), 475-489. https://doi.org/10.1016/s0148-6195(97)00034-9.

Mebratu, M. 2020. Determinants of Inflation in Ethiopia. Working Paper - Chr. Michelsen Institute, 2(18), 68-88.

Mehmet, E. 2017. Short-term and long-term relationships between gold prices and precious metal (Palladium, silver and platinum) and energy (crude oil and gasoline) prices. Economic Research-Ekonomska Istrazivanja, 30(1), 499-510. 
https://doi.org/10.1080/1331677X.2017.1305778.

Murad, M., Beyan, A. 2021. Short-Run and Long-Run Relationships between Economic Growth, Inflation, Exchange Rate and Remittance in Ethiopia: Application of Vector Error Correction Model Approach. East African Journal of Sciences, 15(1), 51-60.

Osborn, O., Mukras, M., Momanyi, G. 2016. The Determinants of Inflation in the Kenyan Economy. International Journal of Economics, 1(1), 46-60.

Pradhan, R.P., Bagchi, T.P. 2013. Effect of Transportation Infrastructure on Economic Growth in India: The VECM approach. Research in Transportation Economics, 38(1), 139-148. https://doi.org/10.1016/j.retrec.2012.05.008.

Rahim, M., Adam, P., Millia, H., Suriadi, L.O., Saidi, L.O. 2021. The Causal Relationship between Fuel Consumption, Exchange Rates and Economic Growth in South East Sulawesi, Indonesia. International Journal of Energy Economics and Policy, 11(6), 1-6.

Raphael, T.M. 2012. An analysis of the Statistical Relationship between Precious Metals Prices and Other Monetary Policy Variables and Inflation in South Africa. Corporate Ownership and Control, 9(2), 420-437. https://doi.org/10.22495/cocv9i2c4art4.

Saira, T., Sadia, B. 2013. An Analysis of the Relationship between Inflation and Gold Prices: Evidence from Pakistan. The Lahore Journal of Economics, 18(2), 1-35. https://doi.org/10.35536/lje.2013.v18.i2.a1.

Teamrat, K. 2017. Determinants of Inflation in Ethiopia: A Time-Series Analysis. Journal of Economics and Sustainable Development, 8(19), 1-6.

Wondimu, E.M. 2020. Determinants of Inflation in Africa: A Systematic Review. International Journal of Management and Fuzzy Systems, 6(4), 59-63. https://doi.org/10.11648/j.ijmfs.20200604.11.

Yen Chee, L., Sek, S.K. 2015. An Examination on the Determinants of Inflation. Journal of Economics, Business and Management, 3(7), 678-682. https://doi.org/10.7763/joebm.2015.v3.265. 